\title{
I. SVETOVNI KONGRES TURIZMA NA KMETIJI
}

\author{
Bolzano, Italija, 7.-9. II. 2018
}

EURAC Research iz Bolzana je v novembru 2018 privabil dvesto udeležencev iz 42 držav na 1. svetovni kongres o turizmu na kmetiji. Koncept in poimenovanje se med državami zelo razlikujeta: programski odbor se je zato praktično in pogumno odločil uporabiti izraz »agriturizem«, ki ga v slovenščini lahko nadomestimo s »turizmom na kmetiji«. V svetovnem smislu je turizem na kmetiji običajno prepoznan kot oblika nišnega turizma, ki pa ima pomembno vlogo v sodobnih turističnih razvojnih trendih. Ključna značilnost turizma na kmetiji je delujoča kmetija in z njo povezano kmečko gospodinjstvo (običajno večgeneracijsko), saj le-temu omogoča diverzifikacijo dejavnosti in dodaten dohodek na kmetiji. Z različnimi proizvodi in storitvami, ki dosegajo obiskovalce in turiste, lahko kmetija pomembno okrepi marsikdaj skromen dohodek iz osnovne kmetijske dejavnosti. Obenem je turizem na kmetiji širše prepoznan kot primer trajnostnega turizma, ki že leta pridobiva na pomenu.

Nikakor ni naključje, da je bil prvi svetovni kongres organiziran prav na Južnem Tirolskem: tu ima turizem na kmetiji že dolgo tradicijo, saj so prebivalci Bolzana in Merana od 19. stol. dalje preživljali svoje počitnice na kmetijah okoliških gorskih vasi. Danes kar 2800 od skupaj 20.000 kmetij tega območja nudi različne vrste turističnih storitev in proizvodov, ki so vezani na njihovo pridelovalno usmeritev (od živinorejskih visokogorskih do sadjarskih in vinogradniških kmetij). S pomočjo blagovne znamke »Roter Hahn« (povezuje 1700 kmetij), ki je prepoznana kot ena uspešnejših na svetovni ravni, kmetje učinkovito tržijo s turizmom povezane storitve na kmetiji vse od leta 1998. Blagovna znamka večinoma povezuje majhne kmetije, katerih družinski člani so močno vpeti v dobro organizirana in razvojno naravnana družinska podjetja. Ob priključitvi k tej blagovni znamki se kmetje zavežejo: (1) da bodo polovico vseh proizvodov, ki jih bodo ponudili obiskovalcem in turistom, pridelali sami; (2) da se bo njihova družina veliko ukvarjala z obiskovalci in vzpostavila avtentičen odnos; (3) da bo kmetija razvijala lastne proizvode.

Izjemno dobro organiziran kongres je udeležencem omogočil različne načine pridobivanja in izmenjave informacij: s plenarnimi predavanji (13), delom v več vzporednih sekcijah (15 sekcij s 54 predavanji), ogledi izbranih dobrih praks na turističnih kmetijah Južne Tirolske, okroglo mizo, s predstavitvijo posterjev, ciljnim mreženjem ter vzpostavitvijo mednarodne platforme na področju turizma na kmetiji.

Slovenska geografija ima tako na področju obravnave turizma na podeželju kot tudi turizma na kmetiji (kot dopolnilne dejavnosti na kmetiji) bogate izkušnje. V letu 2012 smo v Medani organizirali mednarodno »pametno« konferenco s tematiko turizma na kmetiji ter njegove ukoreninjenosti $\mathrm{v}$ lokalno okolje in vpetosti $\mathrm{v}$ mednarodne tokove. Leta 2016 je v zbirki GeograFF izšla monografija (Ne)raba razpoložljivih virov na kmetijah v Sloveniji, kjer je med obravnavo dopolnilnih dejavnosti na kmetiji v pomembnem obsegu zastopan prav turizem na kmetiji. Na tokratnem prvem svetovnem kongresu sva članici Oddelka za geografijo FF UL, ki sva bili tudi edini slovenski predstavnici, poleg 
orisa slovenskih razmer posebej izpostavili različne pristope v raziskovanju in aktualne težnje v razvoju. Slovenski pristop k razvoju turizma na kmetiji, s katerim se ukvarja 1032 kmetij (v letu 2017), se je v mednarodni primerjavi izkazal za zelo uspešnega. Posredovanje slovenskih izkušenj na tem področju je pomembno obogatilo živahne razprave; na razvitost te oblike turizma v Sloveniji smo lahko upravičeno ponosni, saj je bilo Združenje turističnih kmetij ustanovljeno že leta 1997.

Povzamemo lahko, da se pri uveljavljanju različnih oblik turizma na kmetiji države z različnih delov sveta soočajo z nekaterimi zelo sorodnimi problemi: sobivanje tradicionalnih in sodobnih pogledov na turizem na kmetiji, usklajevanje interesov različnih deležnikov, generacijski prenos, vloga turizma na kmetiji v sklopu razvoja podeželja ipd.

Naslednji kongres bo čez štiri leta. Več informacij z dogodka, predstavitve ter povezave lahko spremljate na spletni povezavi http://agritourism.eurac.edu/

\section{Irma Potočnik Slavič in Barbara Lampič}

Blagovna znamka »Roter Hahn« obiskovalcem turističnih kmetij na Južnem Tirolskem zagotavlja visoko kakovost storitev, vezanih na tradicijo, lokalne pridelke in proizvode ter avtentičnost (foto: B. Lampič).

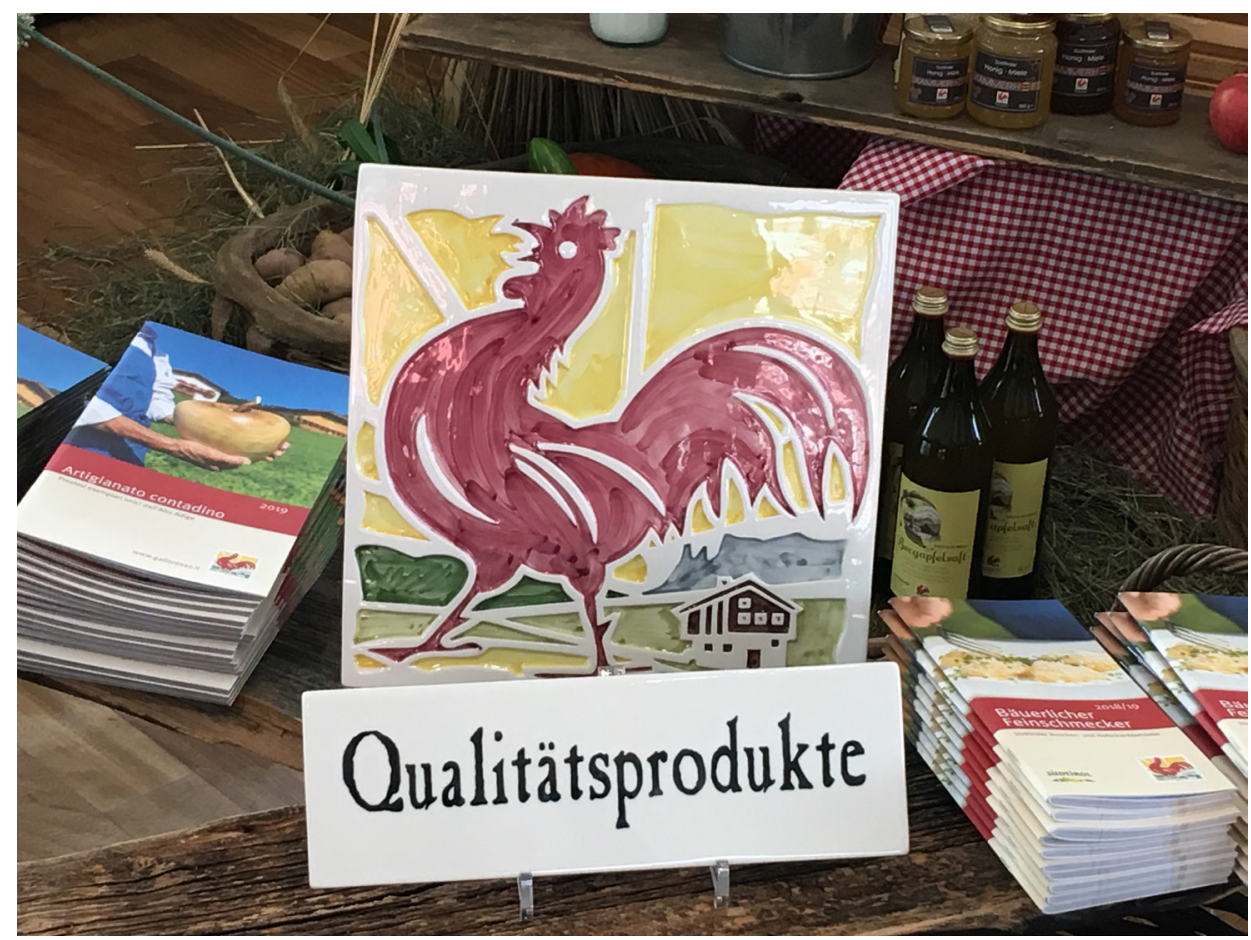

